\title{
Dynamic Morphologic Change and Differentiation from Fetal to Mature Pancreatic Acinar Cells in Rats
}

\author{
Tomoko Inagaki $i^{1}$, Takuma Tajiri², Genshu Tate, \\ Toshiaki Kunimura ${ }^{3}$ and Toshio Morohoshi ${ }^{1}$ \\ ${ }^{1}$ First Department of Pathology, Showa University School of Medicine \\ ${ }^{2}$ Department of Pathology, Showa University Fujigaoka Hospital \\ ${ }^{3}$ Department of Pathology, Showa University Northern Yokohama Hospital
}

\begin{abstract}
Background/Aims: Because of the notion that pancreatic and duodenal homeobox 1 (PdX1)-positive cells are pancreatic stem cells that contribute to the differentiation and proliferation of exocrine cells, we examined PdX-1-associated changes in the morphology of rat pancreatic acinar cells that occur between the late fetal and early neonatal periods.

Methods: Light and electron microscopy and PdX-1 and MIB-5 immunohistochemistry were used to examine pancreatic tissues obtained from fetal rats 22 days postconception (dpc), from newborn rats 48 and 72 hours after natural birth, and from rats 7 days after natural birth.

Results: At $22 \mathrm{dpc}$, the cytoplasm of the acinar cells was large and eosinophilic due to accumulation of dense and numerous zymogen granules. Zymogen granules, rough endoplasmic reticulum, and other organelles were distributed throughout the cytoplasm. At 48 hours, i.e., just after feeding, the cytoplasm appeared smaller, less eosinophilic, and vacuolated. Electron microscopic examination showed cleaved nuclei and fewer zymogen granules. Expression of both PdX-1 and MIB-5 was increased at 48 hours. At 72 hours, acinar cell cytoplasm was decreased in size. At 7 days, the acinar cells were larger, biphasic distribution of zymogen granules was seen on the eosinophilic apical side, and rough endoplasmic reticulum and other ergastoplasms were seen on the basophilic basal side, typical of mature pancreatic acinar cells. Expression of PdX-1 and MIB-5 was markedly decreased in acinar cells.

Conclusion: Our findings indicate dynamic PdX-1-associated morphologic change from fetal to mature pancreatic acinar cells between 48 and 72 hours after birth.
\end{abstract}

(J Nippon Med Sch 2012; 79: 335-342)

Key words: pancreatic and duodenal homeobox 1, reconstruction, acinar cell, differentiation

\section{Introduction}

Differentiation of pancreatic duct cells begins in the primordia and is stimulated by mesenchymal cells. Both endocrine cells and exocrine cells develop from pancreatic duct cells ${ }^{1.2}$. It has recently been shown that damage to pancreatic endocrine cells is

Correspondence to Tomoko Inagaki, First Department of Pathology, Showa University School of Medicine, 1-5-8

Hatanodai, Shinagawa-ku, Tokyo 142-0064, Japan

E-mail: tmkooo@med.showa-u.ac.jp

Journal Website (http://www.nms.ac.jp/jnms/) 
followed by the regeneration and proliferation of residual endocrine cells or the differentiation of ductal precursor epithelial cells. Understanding the mechanism underlying these phenomena could be useful in treating diabetes mellitus ${ }^{3-6}$. In contrast to what is known regarding the pancreatic endocrine system, little is known about the regeneration of the pancreatic exocrine system ${ }^{7-9}$. Once pancreatic acinar cells have been injured, complete regeneration is believed to be difficult because most pancreatic cells are differentiated.

Pancreatic and duodenal homeobox 1 (PdX-1), also known as somatostatin transactivating factor 1 , islet duodenal homeobox 1 , and insulin promoter factor 1 , regulates insulin gene transcription via the Aelement of the insulin promoter and may be involved in glucose-mediated upregulation of insulin gene expression ${ }^{10}$. PdX-1 plays a key role in development of the pancreas; mice with targeted disruption of the PdX-1 gene are born without a pancreas $^{11}$. PdX-1 is expressed throughout the pancreas in the early stages of embryogenesis but is restricted to the islets in adult mice. However, PdX-1 has been shown to be significantly re-expressed in proliferating ductal cells during pancreatic regeneration in an adult racine pancreatectomy model ${ }^{11}$.

Islet duodenal homeobox 1 (i.e., PdX-1)-positive duct cells have been identified in rat pancreas after partial resection, and proliferation of ductal cells and expression of PdX-1 have been observed immediately after 90\% pancreatomy, with levels peaking 2 to 3 days later $^{12}$. In addition, proliferation of pancreatic duct cells and increased positivity for PdX-1 have been observed 1 to 3 days after the induction of pancreatitis in rats $^{13}$. The PdX-1-positive cells may be pancreatic stem cells that contribute to the differentiation and proliferation of exocrine cells of the pancreas 9 .

In the present study, we analyzed the morphologic change of rat pancreatic acinar cells by immunohistochemical staining for PdX-1.

\section{Materials and Methods}

\section{Animals}

Ten adult Wistar rats $(8$ pregnant females and 2 males) (JLA: Wistar rats; Nippon Ikagaku Dobutsu Co., Tokyo, Japan) were obtained and used for the study. Thirty-six neonatal offspring, aged 0 to 7 days, were used for experiments. The neonatal rats were divided into 4 groups according to age at the time of the experiments: 22 days postconception $(d p c)$, i.e., upon live surgical birth at full term $(n=9)$, 48 hours after birth $(\mathrm{n}=9), 72$ hours after natural birth $(n=9)$, and 7 days after natural birth $(n=9)$, with the day on which the vaginal plug was detected taken as $1.0 \mathrm{dpc}$. All adults rats were give standard feed (Oriental Yeast Industrial Company MF, Tokyo, Japan) and water ad libitum. With the exception of the 22-dpc fetuses, the newborn rats were kept with their mothers, and there was no restriction on nursing. The 8 pregnant rats and 6 rats in each group were killed by administration of carbonic acid gas on the respective days specified above, and the pancreas of each rat was removed via an incision in the abdominal wall. The experimental protocol was approved by the Institutional Animal Care and Use Committee of Showa University, which operates in accordance with Law No. 105 of the Japanese Government for the care and use of laboratory animals.

\section{Histopathologic Analysis}

\section{Light Microscopy}

All specimens were fixed overnight in $10 \%$ neutral buffered formalin, embedded in paraffin, and cut into $3-\mu \mathrm{m}$-thick sections. Each section was stained with hematoxylin-eosin and examined histologically with light microscopy, generally at $\times 200$ magnification.

\section{Electron Microscopy}

Pancreatic tissues were fixed with $2.5 \%$ glutaraldehyde and postfixed with $1 \%$ osmium tetroxide. After dehydration in a graded series of ethanols and then in propylene oxide, the samples were embedded in epoxy resin. Ultrathin sections were stained with uranyl acetate and lead citrate, and images of sections were then obtained with an 

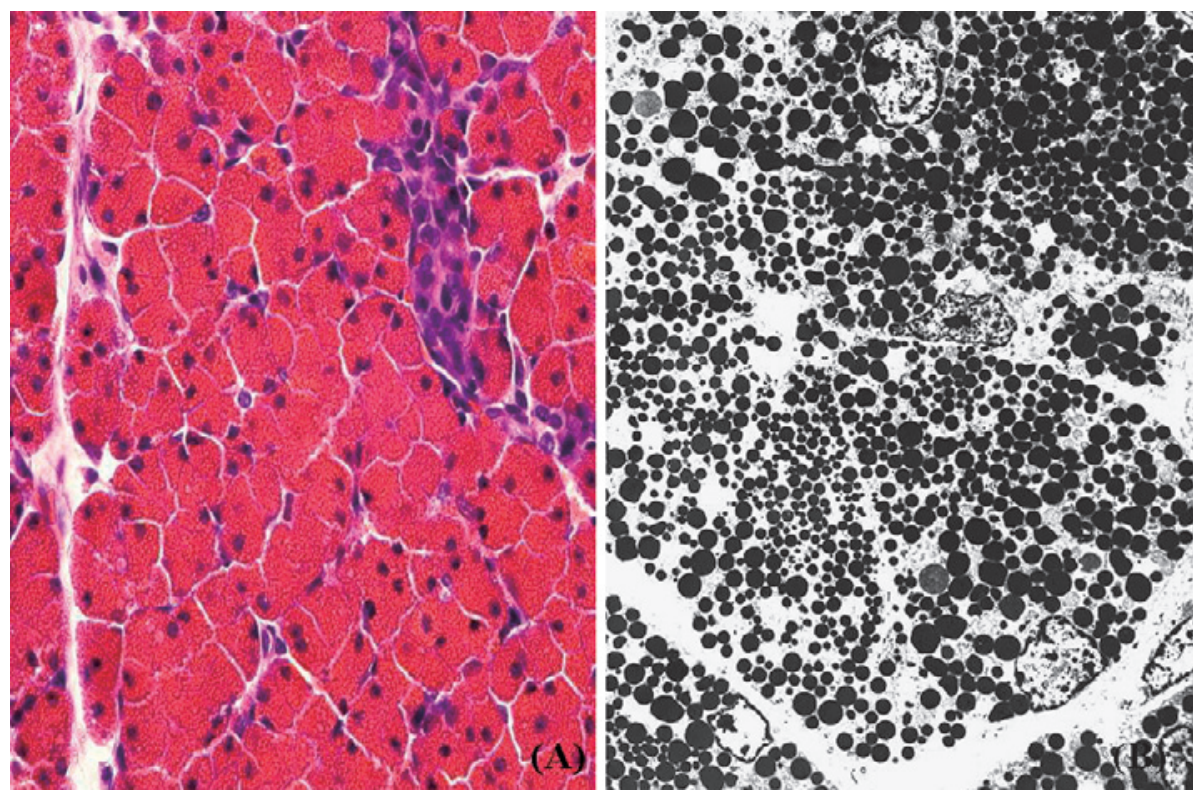

Fig. 1 Acinar cells at 22 days postconception (dpc).

(A) Under light microscopy with hematoxylin and eosin staining, large acinar cells with eosinophilic granular cytoplasm are seen. Nuclei are small and densely basophilic (magnification $\times 200$ ).

(B) Electron microscopy revealed many heterogeneous zymogen granules throughout the cytoplasm (magnification $\times 1,000$ ).

electron microscope (H-7000, Hitachi, Tokyo, Japan). Pancreatic acinar cells were the focus of analysis.

Immunohistochemistry

Expression of PdX-1 and MIB-5 was evaluated immunohistochemically. Three-micrometer-thick sections of formalin-fixed, paraffin-embedded tissue samples were used for immunohistochemical staining performed with the labeled streptavidinbiotin method. For antigen retrieval, $1 \mathrm{mmol} / \mathrm{L}$ EDTA was obtained for MIB-5 immunostaining. The sections were incubated with anti-human MIB-5 antigen monoclonal antibodies (1: 100, DakoCytomation, Glostrup, Denmark) or PdX-1 monoclonal antibody (1:50, Abnova, Taipei, Taiwan) for 32 minutes. Sections were then incubated for 8 minutes with anti-goat secondary antibody. Detection of the immunoreaction was achieved with 3,3'-diaminobenzidine tetrahydrochloride (DAB).

The number of acinar cells with PdX-1-positive nuclei per 100 cells (labeling index, LI, reported as a percentage) in a randomly selected area in each of 3 microscopic fields was calculated at $\times 200$ magnification, and the count was confirmed morphologically with electron microscopy. The MIB-

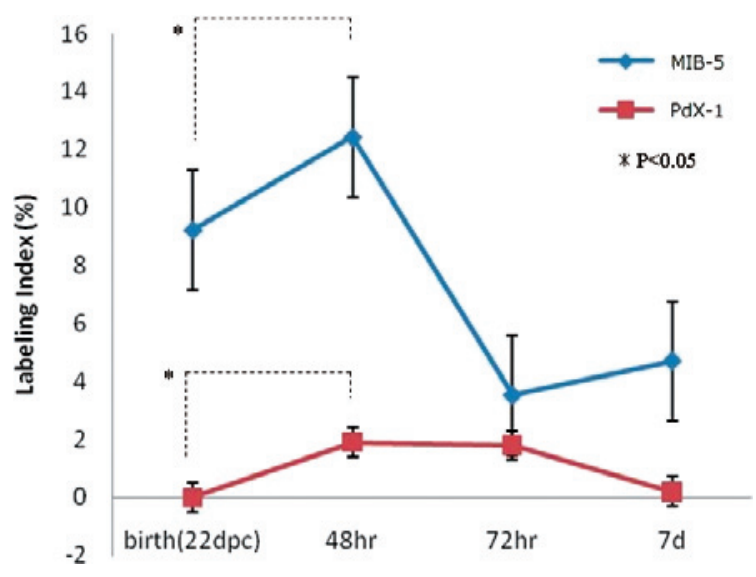

Fig. 2 Percentages of MIB-5-positive and PdX-1positive neonatal rat pancreatic acinar cells (MIB-5 and PdX-1 labeling indices from 22 dpc to 7 days after birth. No PdX1 expression was seen from conception to birth. However, the PdX-1 labeling index had increased to $1.9 \%$ and $1.8 \%$ at 48 hours and 72 hours, respectively, after birth. Seven days after birth, the PdX-1 labeling index had decreased to $0.2 \%$ (dpc, days postconception). ${ }^{*} \mathrm{P}<0.05$. 

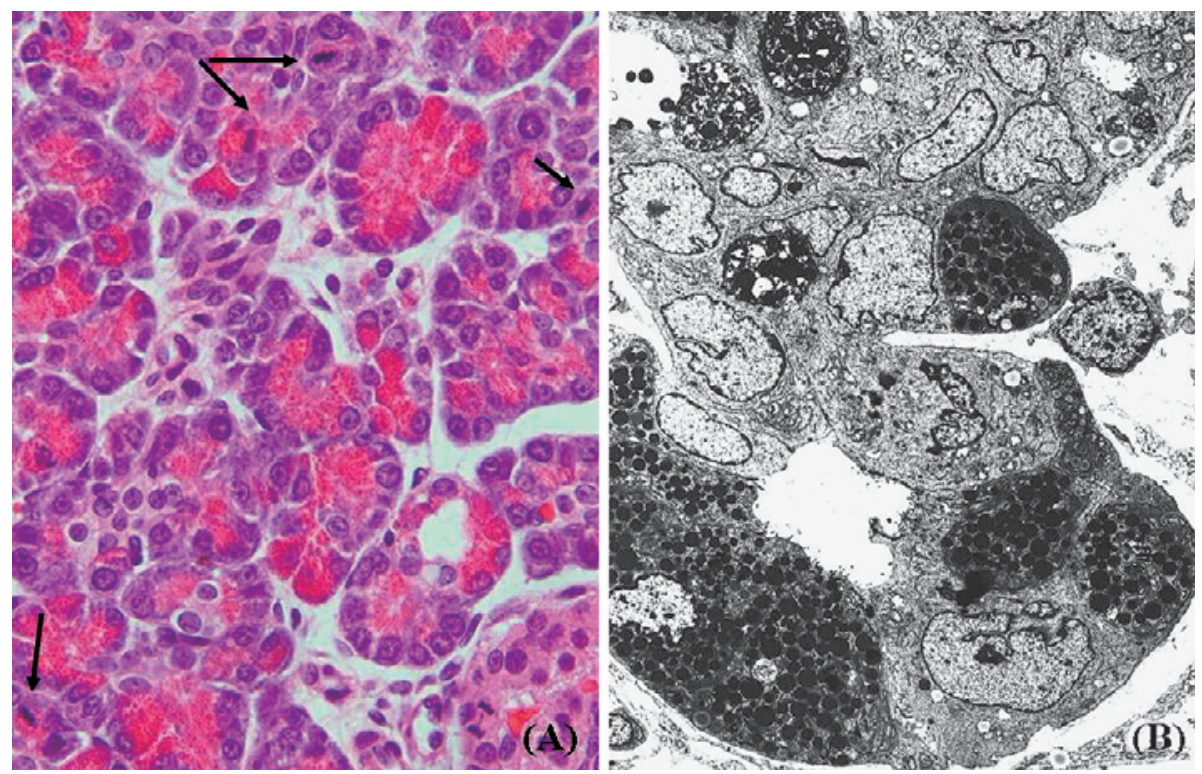

Fig. 3 Acinar cells 48 hours after birth.

(A) Under light microscopy with hematoxylin and eosin staining, the cytoplasm of acinar cells was smaller and less eosinophilic. Hyperchromatic elongated nuclei are observed in some acinar cells (arrows) (magnification $\times 200$ ).

(B) Under electron microscopy, cleaved nuclei and decreased numbers of zymogen granules are observed (magnification $\times 1,000$ ).

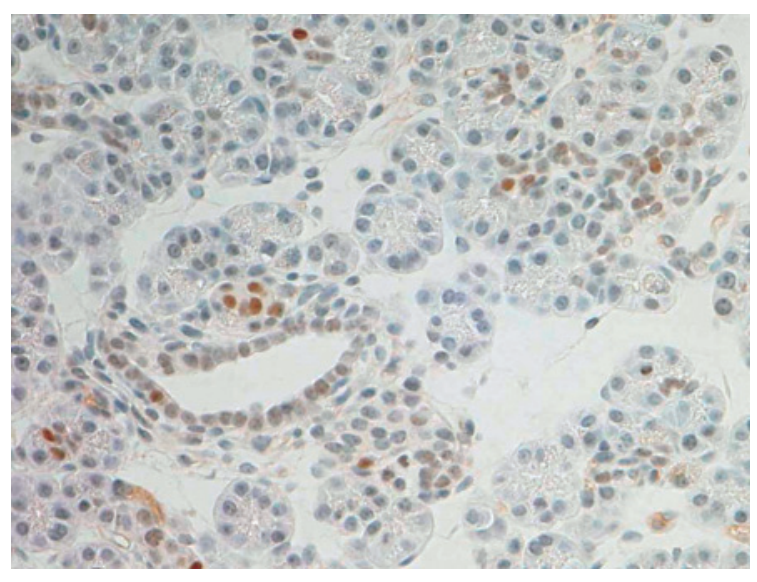

Fig. 4 Immunohistochemistry for PdX-1 in acinar cells 48 hours after birth. Scattered acinar cells are seen (magnification $\times 200$ ).

5 LI was determined at $\times 100$ magnification.

\section{Statistical Analysis}

All data are expressed as mean $\pm \mathrm{SD}$. Student's $t$ test was used for analysis of differences between groups, and $\mathrm{p}<0.05$ was considered to indicate

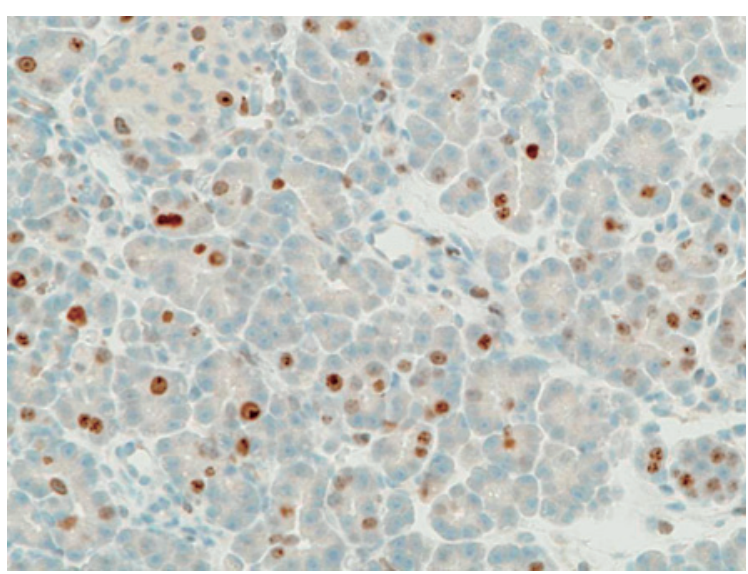

Fig. 5 Immunohistochemistry for MIB-5 48 hours after birth. Immunohistochemistry for MIB5 confirmed the proliferation of PdX-1positive cells (magnification $\times 200$ ).

statistical significance.

\section{Results}

\section{Histologic Findings at Birth (22 dpc)}

The small pancreatic lobules of the 22-dpc fetal 


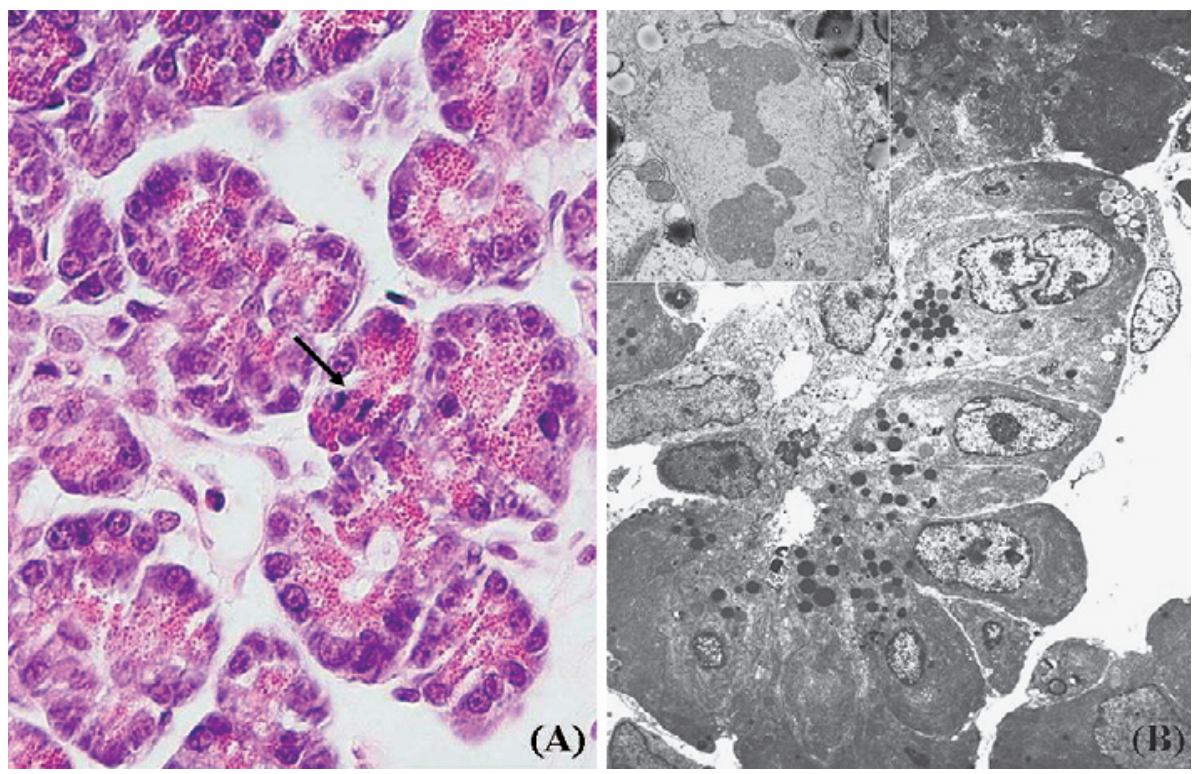

Fig. 6 Acinar cells 72 hours after birth.

(A) Under light microscopy with hematoxylin and eosin staining, the cytoplasm of acinar cells appears to be of minimum size and basophilic. Paired hyperchromatic nuclei (arrow) are observed in acinar cells (magnification $\times 200$ ).

(B) Under electron microscopy, zymogen granules are seen on the apical side, and ergastoplasm is seen on the basal side (magnification $\times 1,000$ ).

(inset) Two paired elongated hyperchromatic nuclei in acinar cells confirm mitosis (magnification $\times 6,000$ ).

rats showed remarkable acinus and duct structure, and acinar cells showed abundant, eosinophilic granular cytoplasm. The nuclei were homogeneous and showed dense basophilic staining (Fig. 1A). Under electron microscopy, zymogen granules, which were heterogenous and dense, were numerous and large and distributed throughout the cytoplasm of acinar cells (Fig. 1B). The nuclei of acinar cells were stained positively for MIB-5; the MIB-5 LI was 9.2\%. No PdX-1-positive cells were observed (Fig. 2).

\section{Histologic Findings 48 Hours after Birth}

In 48-hour-old neonates, the cytoplasm of acinar cells was smaller than in 22-dpc fetuses, and vacuolated, pyknotic oval nuclei were observed in some acinar cells (Fig. 3A, arrows). Electron microscopy showed cleaved nuclei and, although distributed throughout the cytoplasm, a decreased number of zymogen granules in the acinar cells (Fig. 3B). Mitosis of acinar and duct cells was confirmed. Acinar cells were scattered throughout and were positive for PdX-1; the PdX-1 LI was $1.9 \%$. The MIB-
5 LI was 12.4\%. The increases in the 2 indices (Figs. $\mathbf{2}, \mathbf{4}, \mathbf{5})$ were significant (in comparison to values at $22 \mathrm{dpc})(\mathrm{p}<0.05)^{14,15}$.

\section{Histologic Findings 72 Hours after Birth}

The cytoplasm of the acinar cells was smaller at 72 hours after birth than at $22 \mathrm{dpc}$ or at 48 hours after birth and was basophilic (Fig. 6A). Mitotic bodies were observed (Fig. 6A, arrow). The PdX-1 LI was $1.8 \%$, i.e., similar to that at 48 hours after birth, but the MIB-5 LI was decreased to 3.5\% (Fig. 2). Electron microscopy showed only a few small zymogen granules in the apical cytoplasm. Dense rough endoplasmic reticulum and mitochondria were seen in the basal cytoplasm (Fig. 6B). Mitotic acinar cells were confirmed (Fig. 6B, inset) and were greater in number at 48 to 72 hours than at $22 \mathrm{dpc}$ or 7 days. Autophagy was observed in acinar cells at 48 and 72 hours after birth.

\section{Histologic Findings 7 Days after Birth}

Pancreatic acinar cells 7 days after birth were amphophilic; eosinophilic apical cytoplasm with fine 


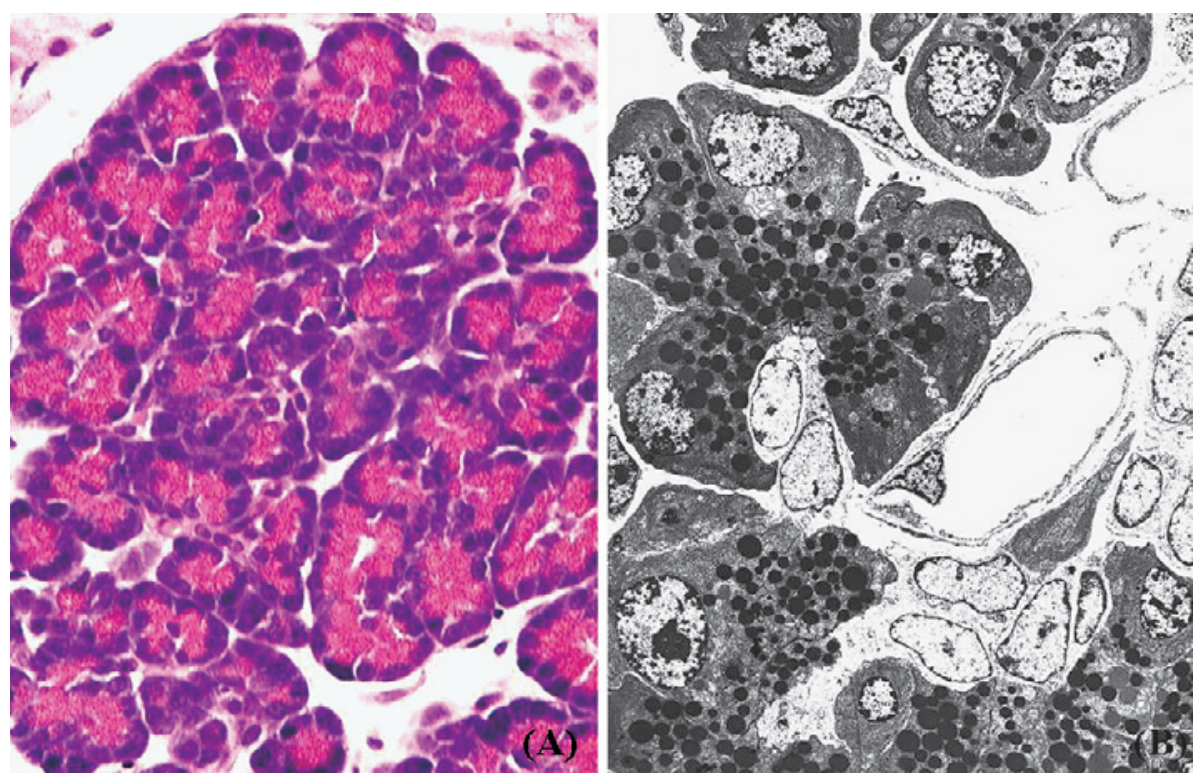

Fig. 7 Acinar cells 7 days after birth.

(A) The basophilic area around the nuclei on the basal side and the eosinophilic area on the apical side were distinctly separated. Hematoxylin and eosin staining (magnification $\times 200$ ).

(B) Under electron microscopy, acinar cells show biphasic distribution of zymogen granules on the apical side and rich rough endoplastic reticulum on the basal side (magnification $\times 1,000$ ).

granules was clearly distinguishable from basophilic basal cytoplasm (Fig. 7A). No pyknotic oval nuclei were observed. The PdX-1 LI and MIB-5 LI were decreased to $0.2 \%$ and $4.7 \%$, respectively (Fig. 2). Electron microscopy showed zymogen granules concentrated in the apical cytoplasm and welldeveloped organelles in the basal cytoplasm (Fig. 7B).

\section{Discussion}

Pancreatic acinar cells are crucial for the digestion and absorption of colostrum in neonatal rats just after birth. The acinar cells contain zymogen granules, which store the trypsin, amylase, and lipase necessary for the digestive enzyme needed for newborn rats to digest their mother's milk. As shown in Figure 1, the zymogen granules in rat acinar cells have already emerged by full term. As also shown, both the number and density of zymogen granules peak by 48 hours after birth. Takeuchi et al. have reported that the number and density of zymogen granules before birth depend on the serum glucocorticoid concentration?
Our findings show that rat acinar cells before birth are morphologically different from mature rat pancreatic acinar cells with respect to the diffuse distribution of organelles, such as intracytoplasmic reticulum and mitochondria, and to the number and size of zymogen granules (Table 1). No biphasic localization of zymogen granules and organelles is observed in pancreatic acini during the late fetal stage because continuous secretion of enzymes from the zymogen granules is unnecessary at this stage. Many enzymes are stored in zymogen granules contained in fetal acinar cells, but autodigestion of the cells does not occur. The stability of pancreatic acinar cells in newborn rats depends on pancreatic secretory trypsin inhibitor ${ }^{16}$. In our study, zymogen granules for digestion of colostrum appeared just after feeding, and the cytoplasm of acinar cells decreased in size and showed vacuole degeneration.

In our study, autophagy was observed 48 to 72 hours after birth. Autophagy plays a key role immediately after birth in mammals ${ }^{17}$. Autophagy usually occurs at extremely low levels but can occur in all somatic cells, especially skeletal muscle cells, cardiac muscle cells, and pancreatic cells, by 
Table 1 Histologic and electron microscopic features of fetal and mature rat pancreatic acinar cells

\begin{tabular}{lll}
\hline & Fetal acinar cells $(22 \mathrm{dpc})$ & Mature acinar cells (adult) \\
\hline $\begin{array}{l}\text { Histopathologic features } \\
\text { Nuclei } \\
\text { Cytoplasm }\end{array}$ & $\begin{array}{l}\text { Small, monotonous } \\
\text { Abundant, } \\
\text { eosinophilic }\end{array}$ & $\begin{array}{l}\text { Large, coarse } \\
\text { Pyramidal, eosinophilic on } \\
\text { the apical side, basophilic } \\
\text { on the basal side }\end{array}$ \\
$\begin{array}{ll}\text { Electron microscopic features } \\
\text { Nuclei }\end{array}$ & $\begin{array}{l}\text { Randomly located, } \\
\text { blastic } \\
\text { Abundant, rich in dense } \\
\text { Zytoplasm }\end{array}$ & $\begin{array}{l}\text { Located on the basal side, } \\
\text { slightly coarse } \\
\text { Biphasic, with zymogen } \\
\text { granules on the apical }\end{array}$ \\
& $\begin{array}{l}\text { immature rER, and } \\
\text { side, rER and } \\
\text { mitochondria }\end{array}$ & $\begin{array}{l}\text { mitochondria on the basal } \\
\text { side }\end{array}$ \\
\hline
\end{tabular}

dpc: days post conception, rER: rough endoplasmic reticulum
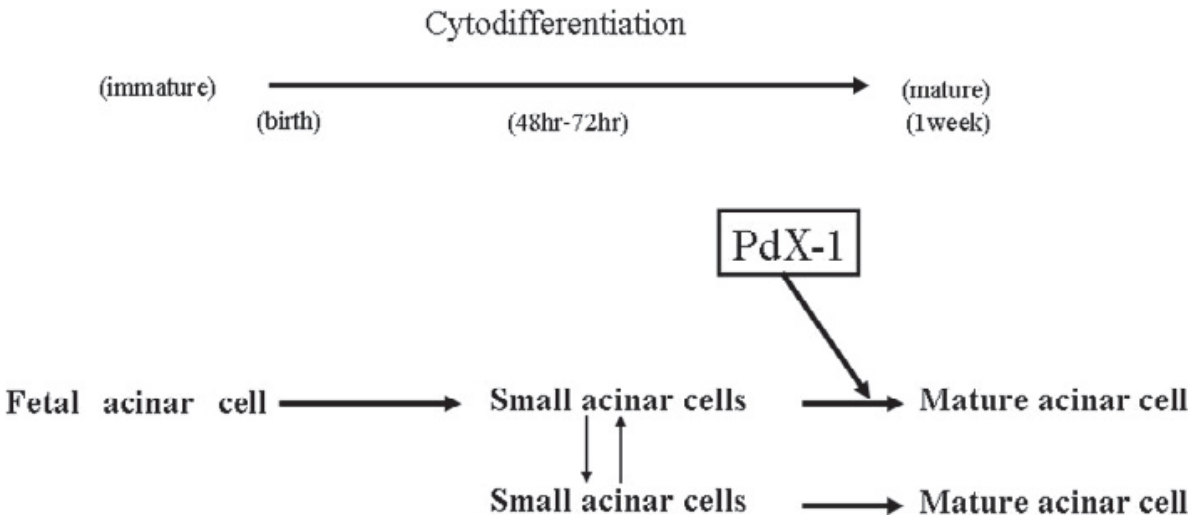

Fig. 8 Diagram of rat pancreatic acinar cell differentiation. Fetal acinar cells change morphologically into small acinar cells by release of zymogen granules after feeding. PdX-1 is closely related to self-replication and cytodifferentiation of small acinar cells, which change into mature acinar cells.

physiologic starvation. A main role of autophagy is thought to be self-preservation; cells acquire nutrition through self-digestion ${ }^{18}$. Thus, autophagy is extremely important in newborns, who naturally go through a short period of physiologic starvation.

Mitosis of residual acinar cells indicates selfreplication. We observed an increase in PdX-1positive regenerative cells and some MIB-5-positive acinar cells 48 hours after birth. The parallel peaks in PdX-1 and MIB-5 expression at 48 hours after birth occur when neonatal acinar cells decrease in size due to the release of enzymes from zymogen granules in response to nursing (we refer to these cells as small acinar cells), and residual acinar cells proliferate by self-replication to differentiate into mature cells to maintain homeostasis after birth (Fig. 7).

Seven days after birth, the pancreatic acinar cells are increased in size and show biphasic localization of zyomgen granules and intracytoplasmic reticulum. These morphologic changes indicate the differentiation and maturation of pancreatic acinar cells in neonates upon colostrum ingestion.

In our study, PdX-1 expression was found in acinar cells 24 hours after birth, peaked 48 hours after birth (LI 1.9\%), and remained at approximately the same level (LI 1.8\%) until at least 72 hours after birth. Staining for MIB-5 began to increase after birth and reached a peak after 48 hours (LI 12.4\%). The numbers of both MIB-5-positive cells and PdX-1- 
positive cells had decreased by 72 hours after birth. By day 7, the expression levels had decreased markedly from peak levels. As shown in Figure 8, PdX-1 might promote both the proliferation and cytodifferentiation of small acinar cells and, thus, be closely related to acinar cell regeneration ${ }^{1920}$. The dynamic morphologic transformation of pancreatic acinar cells that turns unstable neonatal acinar cells into stable mature acinar cells occurs mainly between 48 and 72 hours after birth.

Our search of the literature revealed no reports with findings similar to ours. Thus, we believe this report to be the first of sequential PdX-1-associated morphologic changes and proliferation of pancreatic acinar cells during the development of fetal and neonatal rats.

In conclusion, we have described herein the proliferation of pancreatic acinar cells in late fetal and early neonatal rats. The proliferation occurs when fetal development ends and independent life begins.

\section{References}

1. Lack EE: Pathology of the Pancreas, Gallbladder, Extrahepatic Biliary Tract, and Ampullary Region, 2003; pp 3-43, Oxford University Press, New York, NY.

2. Klöppel G, Heitz PU: Pancreatic Pathology, 1984; pp 321, Churchill Livingstone, Edingburgh, Scotland.

3. Bonner-Weir S, Baxter LA, Schuppin GT, Smith FE: A second pathway for regeneration of adult exocrine and endocrine pancreas. A possible recapitulation of embryonic development. Diabetes 1993; 42: 17151720

4. Bonner-Weir S: Islet growth and development in the adult. J Mol Endocrinol 2000; 24: 297-302.

5. Slack JM: Developmental biology of the pancreas. Development 1995; 121: 1569-1580.

6. Pick A, Clark J, Kubstrup C, et al:: Role of apoptosis in failure of $\beta$-cell mass compensation for insulin resistance and $\beta$-cell defects in the male Zucker diabetic fatty rat. Diabetes 1998; 47: 358-364.

7. Takeuchi T, Kameya T, Tsumuraya M, Sugimura T:
Development of exocrine cells of the pancreas and parotid gland in rats. Relation between morphological and biochemical changes. Digestion 1978; 18: 266-279

8. Hisaoka M, Haratake J, Yamamoto O: Morphological development of the rat fetal pancreas. J UOEH 1991; 14: $1-12$.

9. Go VLW, Gardner JD, Brooks FP, et al:: The Exocrine Pancreas: Biology, Pathology, and Diseases, 1986; pp 33-43, Raven Press, New York.

10. Jonsson J, Carlsson L, Edlund T, Edlund H: Insulinpromotor-factor 1 is required for pancreas development in mice. Nature 1994; 371: 606-609.

11. Melloul D, Bwn-Neriah Y, Cerasi E: Glucose modurates the binding of an islet-specific factor to a conserved sequence within the rat I and the human insulin promoters. Proc Natl Acad Sci USA 1993; 90: 3865-3869.

12. Sharma A, Zangen DH, Reis P, et al.: The homeodomain protein IDX-1 increases after an early burst of proliferation during pancreatic regeneration. Diabetes 1999; 48: 507-513.

13. Taguchi M, Yamaguchi $\mathrm{T}$, Otsuki M: Induction of PDX-1 positive cells in the main duct during regeneration after acute necrotizing pancreatitis in rats. J Pathol 2002; 197: 638-646.

14. Jacobson MD, Weil M, Raff MC: Programmed cell death in animal development. Cell 1997; 88: 347-354.

15. Nagata S: Apoptosis by death factor. Cell 1997; 88: 355-365.

16. Witt H, Luck W, Hennies HC, et al:: Mutations in the gene encoding the serine protease inhibitor, Kazal type 1 are associated with chronic pancreatitis. Nat Genet 2000; 25: 213-216.

17. Kuma A, Hatano M, Matsui M, et al.: The role of autophagy during the early neonatal starvation period. Nature 2004; 432: 1032-1036.

18. Levine B, Klionsky DJ: Development by selfdigestion: molecular mechanisms and biological functions of autophagy. Dev Cell 2004; 6: 463-477.

19. Liu T, Wang CY, Gou SM, Wu HS, Xiong JX, Zhou J: PDX-1 expression and proliferation of duct epithelial cells after partial pancreatectomy in rats. Hepatobiliary Pancreat Dis Int 2007; 6: 424-429.

20. Burlison JS, Long Q, Fujitani Y, Wright CV, Magnuson MA: Pdx-1 and Ptfla concurrently determine fate specification of pancreatic multipotent progenitor cells. Dev Biol 2008; 316: 7486.

(Received, December 26, 2011)

(Accepted, February 10, 2012) 